\title{
Hazard Analysis of Earthquake in the Main Campus of Universitas Pendidikan Indonesia
}

\author{
Lies Wahyuni' ${ }^{1}$, Dede Rohmat ${ }^{2}$, Iwan Setiawan ${ }^{3}$ \\ 1ieswahyuni190695@gmail.com,2dederohmat@upi.edu ,3iwansetiawan@upi.edu \\ 1,2,3 Department of Geography Education, Universitas Pendidikan Indonesia
}

Submitted

August, $11^{\text {th }} 2018$
Revised

November, 20 2018

http://dx.doi.org/10.17509/jpis.v27i2.12426
Accepted

December, 13 2018

\section{ABSTRACT}

This study aims at analyzing the hazard level of earthquake in the main campus Universitas Pendidikan Indonesia (UPI) as a means to improve the preparedness in anticipating disasters. The method used was literature study of which data were analyzed using Geographic Information System (GIS). The analysis of the earthquake zones, the potential frequency, and earthquake magnitude, and the distance from the main campus of UPI to the earthquake zone shows that the danger level is high. In terms of zone, the main campus of UPI is located is in the red zone based on the earthquake disaster risk index from the Indonesian National Board for Disaster Management (BNPB) and the earthquake zoning map from the Indonesian Ministry of Public Works. The main campus of Universitas Pendidikan Indonesia which is located in the northern part of Bandung, belongs to the Severe VIII zone meaning that significantly dangerous earthquake resulting in moderate to severe damage possibly occurs. The risk level calculation of the disaster based on its danger, tendency, and capacity is yet to conduct, so that it becomes the suggestion.

Keywords: Earthquake, Hazard, Campus of Universitas Pendidikan Indonesia.

\section{INTRODUCTION}

Geographically, the location of the main campus of Indonesia University of Education are $107^{\circ} 35^{\prime} 11.93^{\prime \prime}$ EL to $107^{\circ}$ $35^{\prime} 47.5^{\prime \prime} \mathrm{EL}$ and $06^{\circ} 51^{\prime} 25,36^{\prime \prime} \mathrm{SL}$ to $06^{\circ}$ $51^{\prime} 54,3$ ' SL in Bandung, West Java. It is stated that there are 28 regions in Indonesia which are highly prone to tectonic earthquake, volcano and tsunami, including West Java (BNPB, 2011).

According to Van Bemellen, Bandung is located in Bandung zone which constitutes a depression zone in West Java; it means that this zone is located on the main structure or is passed by the main structure in West Java (Van Bemmelen, 2000). These structures potentially cause seismic waves. One of the faults found in Bandung is the Lembang fault and is currently active. According to many researchers, the Indonesian Institute of Sciences (LIPI) with JICA, and the Indonesian the Ministry of Research and Technology, the impact of the Lembang fault shift is predicted to cause landslides and earthquakes of 6-7 richter scale. Earthquake energy reflects its magnitude that occurs due to a fault (Budi W., 2017). This possibly threatens the community and environment in the vicinity of the fault including the main campus of UPI. In addition to the Lembang fault, another earthquake threat comes from Mount Tangkuban 
Parahu which can become active at any given moment and cause an earthquake and volcano. Thus, danger analysis of earthquake in the main campus of UPI is considered to be necessary.

\section{THEORETICAL FRAMEWORK}

\section{Earthquake Disaster}

Disaster is an accident or series of events which threaten and disrupt people's lives and is caused by both natural and/or non-natural factors as well as human factors resulting in human victims, environmental damage, property losses and psychological impacts. On the other hand, natural disaster is a disaster caused by an accident or series of events caused by nature, including earthquake, tsunami, volcanic eruption, flood, drought, hurricane, and landslide (Law no. 24/2007 regarding Disaster Management) (Soehatman, 2010). Such accident is not so-called a natural disaster unless it results in victims and losses.

The focused natural disaster of this study is earthquake. An earthquake is an event of releasing a certain amount of energy in the Earth's lithosphere. One of the energies is a wave energy called seismic waves. This wave is emitted from its source and spreads in all directions, so that it can be detected by a seismic sensor (Ibrahim \& Subardjo, 2005).

Earthquake is an unpredictable natural phenomenon which can occur at any time (Rysnawati, Sukarasa, \& Paramarta, 2009). Earthquake constitutes one of the most damaging natural disasters; it can occur at any time along the year with sudden impacts and little warning. Earthquake can destroy buildings in a short amount of time, kill or injure people in its surrounding. It does not only damage an entire city, but can also disrupt the government, economy and social structure of a country (Lambas, 2009).

Villavarde asserts that earthquake can be caused by: (1) tectonic forces which are closely related to a fault formation as a direct result of interactions among plates forming the Earth's hard outer layer; (2) volcanic earthquake which is related to volcanic activity; (3) mass rock slides; (4) conventional and nuclear explosion; (5) meteorite collisions. Earthquakes caused by volcanic eruption, mass rock slides, conventional and nuclear explosion, meteorite collisions are relatively rare and merely affect a limited area (Villaverde, 2009).

\section{Disaster Hazard}

Hazard is a potential occurrence of a disaster which can result in human victims, injury, and material losses and damage. The Indonesian National Board for Disaster Management states that hazard is a natural or artificial phenomenon which potentially damages human life and cause material loss and environmental damage (Bakornas PB, 2007).

Hazard is a potentially damaging physical event, phenomenal or human activity that may cause loss of life or injury, property damage, social and economic disruption or environmental damage. Hazard can include hidden conditions that may represent future threats. They can have different origins: natural (geological, hydro meteorological and biological) or environmental degradation and technological hazards. Hazard can be single, sequential or combined depending on their origin and impact. Each hazard is characterized by location, intensity, frequency and probability (ISDR, 2004). 
There are several efforts to initially anticipate hazard, one of which is an earthquake warning to reduce the impact caused in terms of both material losses and human victims (Shohaya et al., 2013). Hazard is a parameter in determining the risk of an unavoidable disaster; knowing the hazard level, however, can increase the preparedness.

\section{RESEARCH METHOD}

The case study is regarding Earthquake hazard analysis in the main campus of Indonesia University of Education or UPI Bumi Siliwangi which is located in Bandung, West Java. The method used was literature review and analysis from Geography Information System. The earthquake hazard analysis was performed based on hazard parameters: location with earthquake zones, potential, frequency, and earthquake magnitude, as well as the distance from the main campus of Indonesia University of Education to the earthquake zones.

\section{RESULT AND DISCUSSION \\ Location with the Earthquake Zone}

Location is one of the hazard parameters. In terms of location, Indonesia is at high risk in terms of disaster occurrence. Maryani states that Indonesia is a country that is prone to disaster as it is located among Asia, Pasific, Hindia plates. Based on plate tectonic theories, great energy is stacked in sub-diction zone. When the energy reaches its maximum level, it can lead to an earthquake or seism. Indonesia is one of the countries that frequently hit by tectonic earthquake as it is surrounded by sub-diction zone (Maryani \& Furqan, 2016).

Based on its location, the main campus of Indonesia University of
Education is one of the campuses that are prone to disasters, especially earthquake. To identify the risk, it can be seen from the Earthquake Disaster Risk Index of Indonesia from Indonesian National Board for Disaster Management (in Indonesia it called BNPB) and the Indonesian Ministry of Public Works as presented in Figure 1 and Figure 2.

Based on the Earthquake Disaster Risk Index of Indonesia, Bandung is in the red zone which means that the risk earthquake occurrence is significantly high. Similarly, based on the Indonesian Ministry of Public Works' Earthquake Zoning Map of Indonesia, it can be identified that Bandung is in the dark red zone which means high frequency and high magnitude earthquakes are most likely to occur. Based on both shown figures, the main campus of Indonesia University of Education located in Bandung has the same high risk.

\section{Potential, Frequency and Magnitude of Earthquake}

Tectonic earthquake is one of the commonly feared natural disasters because it causes great losses, especially earthquake which occur at high magnitude. This disaster cannot be determined regarding its how and when; however, an approach can be taken to predict its occurrence by various methods. One method to analyze the seismic activity of a region as a mitigation effort is to analyze the relationship between its frequency and magnitude (Rohadi, 2015). The earthquake source in the main campus of UPI is Lembang Fault. The activity of Lembang Fault has not been well identified; hence, a more integrated study employing several methods to determine the wave potential (Rasmid, 2014b). 


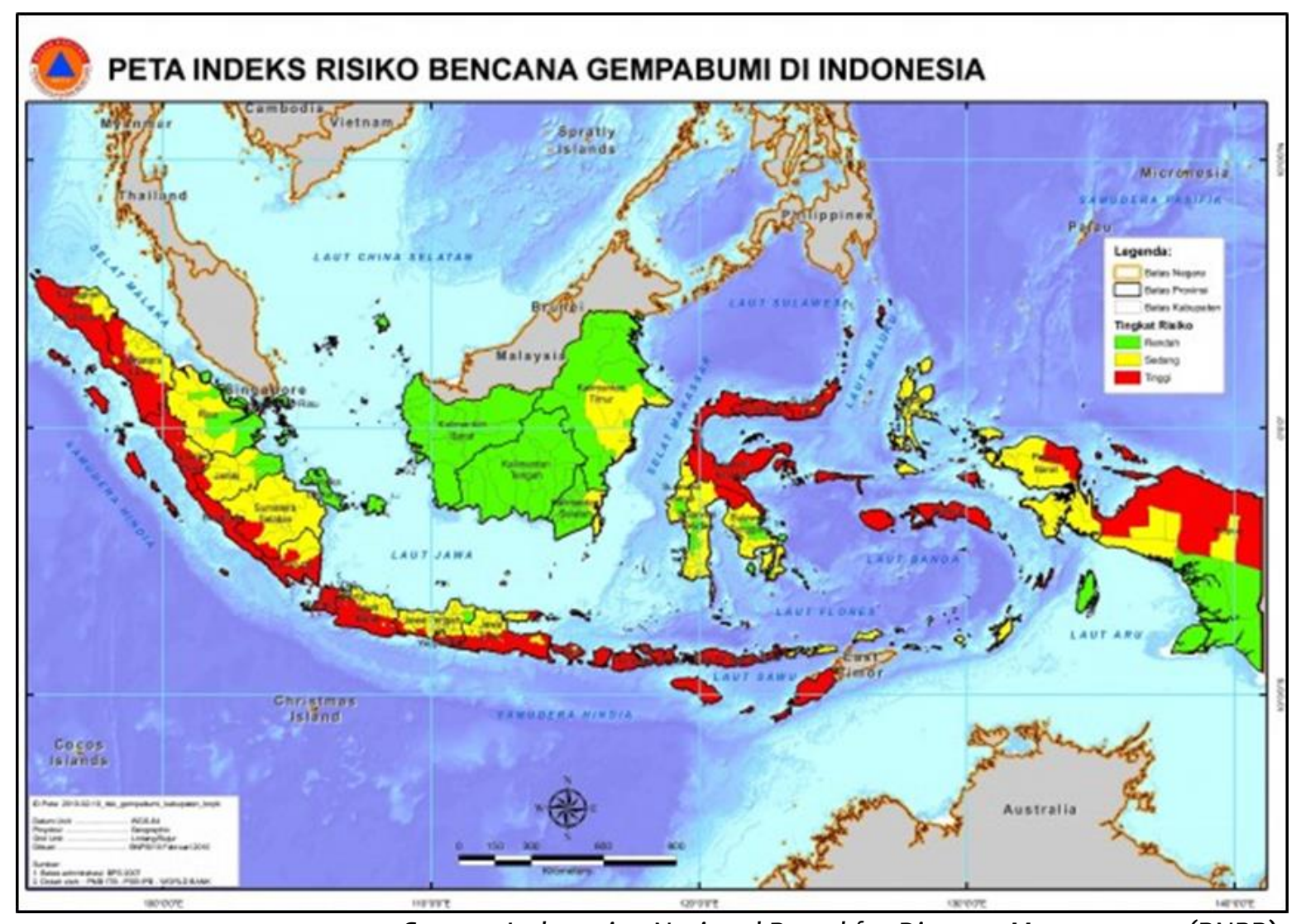

Source: Indonesian National Board for Disaster Management (BNPB)

Figure 1. The Earthquake Disaster Risk Index of Indonesia

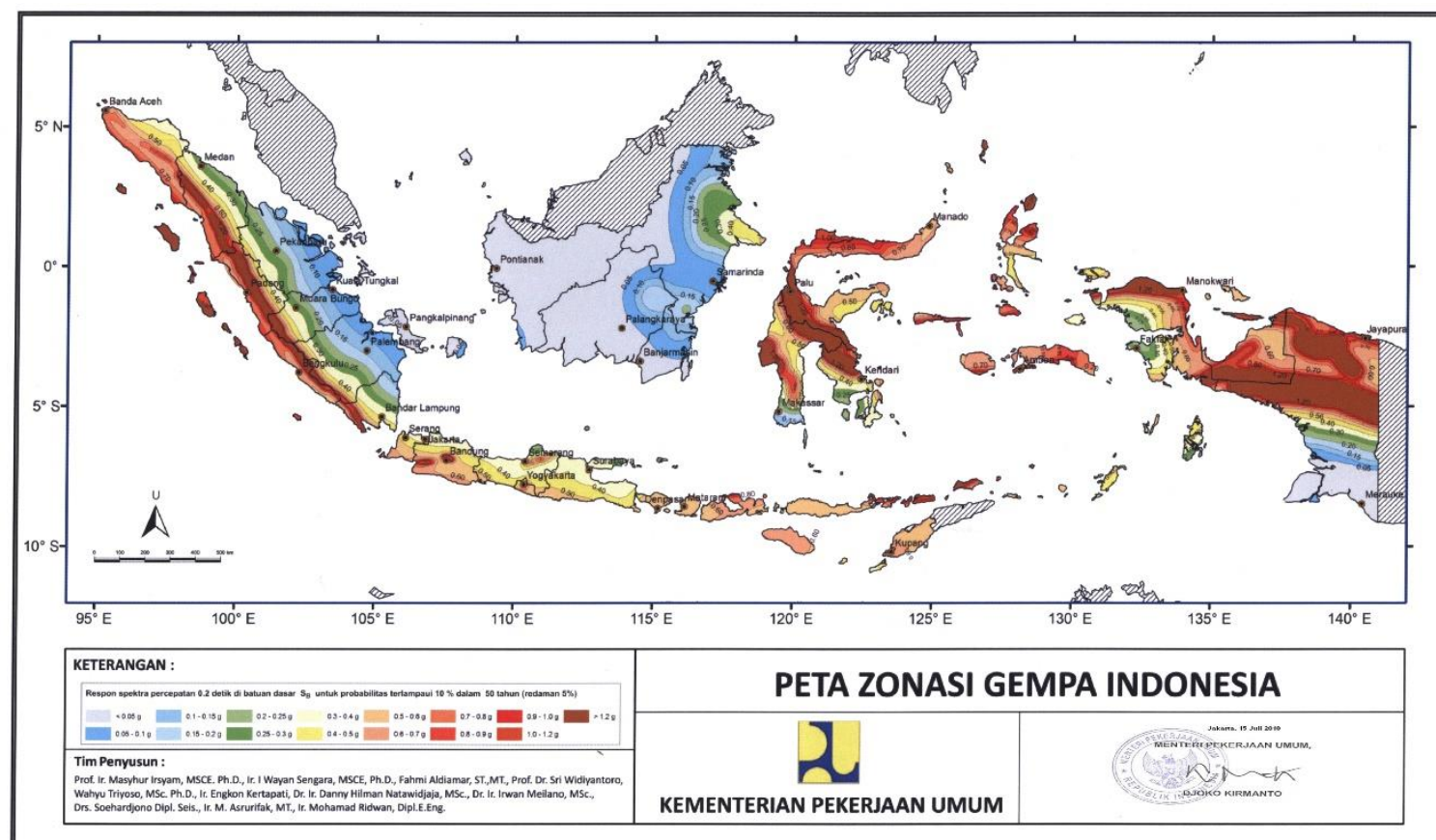

Source: Indonesian Ministry of Public Works

Figure 2 The Earthquake Zoning Map of Indonesia 
Based on GPS data, Lembang Fault is an active fault and is proven by the fault shift activity despite the small rate of 0.3 to $1.4 \mathrm{~cm} /$ year compared to the Indo-Australian plate to the Eurasian plate shift activity of 6-7 cm/year (Abidin et al., 2001; Rasmid, 2014a). However, although the figure is at small rate, it indicates that Lembang Fault remains active.

Such notion supports the result of previous studies in terms of paleoseismology, in which a sag pond is found around the escarpment and also the skeletons of animals and tree trunks are found around Lembang Fault. Yulianto states that such evidence is caused by mass and sudden slide, so that the animals could not save themselves. It can also be caused by an earthquake because the location is close to the fault (Brahmantyo, 2005). Other study supporting the fact that Lembang Fault is an active fault (Hidayat, Brahmantyo, \& Yulianto, 2008).

Fault is an earthquake-prone area; this is due to the fact that in the fault zone the rock density is reduced so that if there is a seismic wave, most of the wave passes through the fault. The result of the study shows that the Lembang Fault shift rate is 5.0 mm/year; likewise, Indonesian Agency for Meteorology, Climatology and Geophysics (BMKG) shows the presence of seismic activities of small rate. The following is an earthquake scenario modeling map by Indonesian Agency for Meteorology, Climatology and Geophysics (BMKG) (See Figure 3).

The result of the shakemap by Indonesian Agency for Meteorology, Climatology and Geophysics (BMKG) of $M=6.8$ with a hypocenter depth of $10 \mathrm{~km}$ in Lembang Fault (shown with thick black line) indicates that the earthquake impact can reach the MMI VII-VIII intensity scale (equivalent to maximum ground acceleration of $0.2-0.4 \mathrm{~g}$ ) with a description of minor damage to strong construction buildings. It can also result in collapsing wall, monuments or towers, and cloudy water.

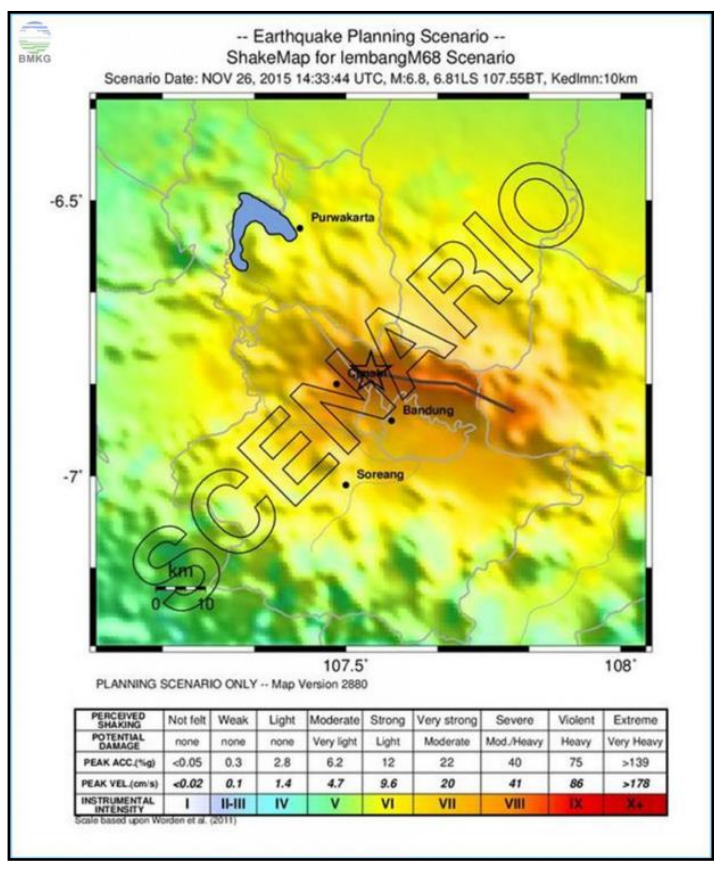

Sumber: BMKG, 2017

Figure 3. Earthquake Scenario Modeling Map of Lembang Fault

In terms of simple non-structural buildings, severe damage can possibly occur which results in the building to collapse. In general, the VII-VIII MMI intensity scale means that significantly dangerous earthquake resulting in moderate to severe damage possibly occurs. In Figure 4.3 , it is known that the main campus of Universitas Pendidikan Indonesia (UPI) which is located in the northern part of Bandung is in the Severe VIII zone; it means that the main campus of UPI is prone to earthquake caused by the Lembang fault shift.

\section{Distance to the Earthquake Zone}

The distance to the potential earthquake zone is one of the risk parameters. The closer a location is to the earthquake zone, the greater the 
hazard. Such distance affects the magnitude and impact of the earthquake.

There are two potential earthquakes close to the main campus of UPI: Lembang Fault and Mount Tangkuban Parahu. Based on analysis using Google Earth, it is known that the closest distance to the main campus of UPI Campus with Lembang Fault is $7 \mathrm{~km}$ and the farthest distance is $14 \mathrm{~km}$; on the other hand, the distance of the main campus of UPI to Mount Tangkuban Parahu is $11.1 \mathrm{~km}$.

Such distance is drawn using a straight line from the main campus of UPI to the earthquake zones that is the Lembang fault and Mount Tangkuban Parahu. The distance from the main campus of UPI to the earthquake zone is considered to be very close, since it is less than $20 \mathrm{~km}$. It means that if at any time the earthquake zone is active, the main campus of UPI is at high risk. The maps regarding the distance from the main campus of Indonesia University of
Education (UPI) to the earthquake zone are presented in Figure 4 and Figure 5.

\section{CONCLUSIONS}

The result of the analysis based on a number of parameters, such as location with earthquake zones, potential, frequency, and earthquake magnitude, as well as the distance from the main campus of Indonesia University of Education to the earthquake zones indicates that the earthquake risk of the main campus of UPI is high. In terms of zone, the main campus of UPI is located in the red zone, based on the Earthquake Disaster Risk Index of Indonesia from Indonesian National Board for Disaster Management (BNPB) and the Earthquake Zoning Map from Indonesian Ministry of Public Works. Furthermore, the main campus of UPI which is located in the northern part of Bandung is classified in the Severe VIII zone which means meaning that significantly dangerous earthquake resulting in moderate to severe damage possibly occurs.

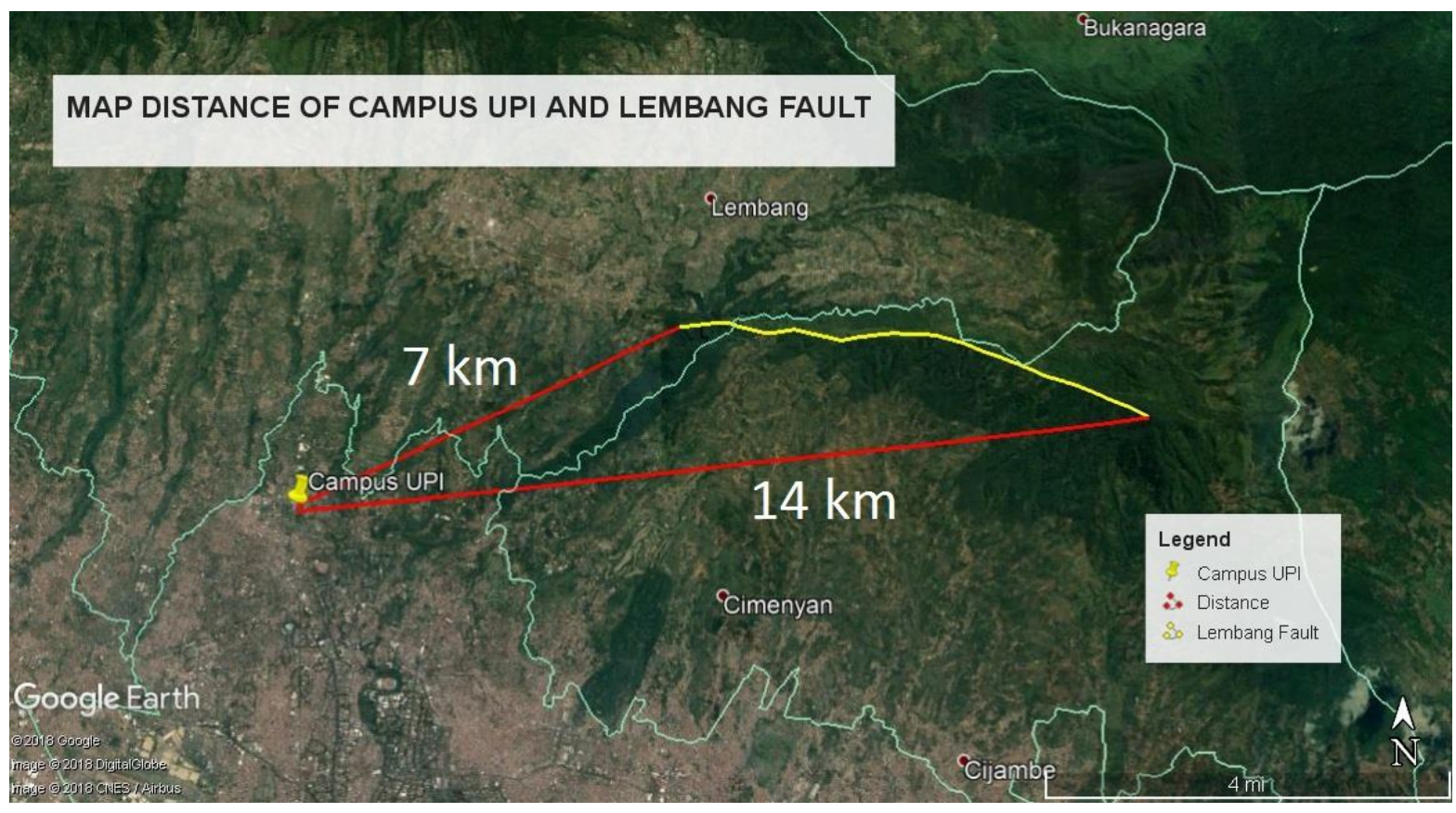

Source: Google Earth Analysis, 2018

Figure 4. The map regarding the distance from the main campus of UPI to Lembang Fault 


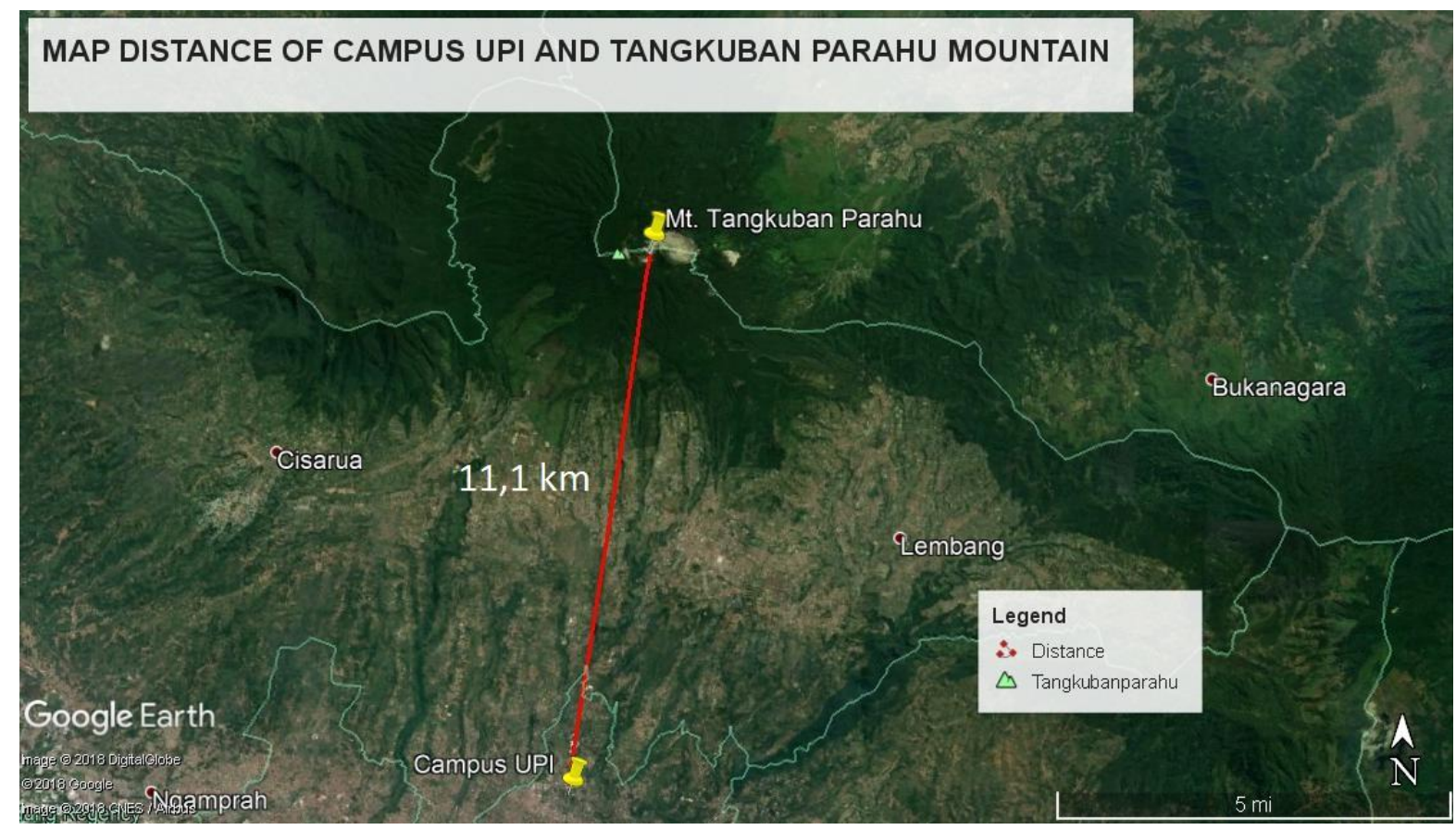

Source: Google Earth Analysis, 2018

Figure 5 The map regarding the distance from the main campus of UPI to Mount Tangkuban Parahu

\section{RECOMMENDATION}

This study merely analyzes in terms of the hazard level. The risk level calculation of the disaster based on its danger, tendency, and capacity is yet to conduct. Therefore, it is suggested to calculate in detail regarding the earthquake risk in the main campus of Indonesia University of Education (UPI).

\section{REFERENCES}

Abidin, H., Djaja, R., Darmawan, D., Hadi, S., Akbar, A., Rajiyowiryono, H., ... Subarya, C. (2001). Land Subsidence of Jakarta (Indonesia) and its Geodetic Monitoring System. Journal of the International Society of the Preventation and Mitigation of Natural Hazards, 23(2), 365-387. https://doi.org/10.1023/A:101114460 2064

Bakornas PB, B. K. P. B. N. (2007). Pengenalan Karakteristik Bencana dan Upaya Mitigasi di Indonesia, edisi II. Jakarta: Pelaksanaan Harian Badan Koordinasi Nasional Penanganan Bencana.

BNPB. (2011). Peraturan Kepala Badan Nasional Penanggulangan Bencana Nomor 17 Tahun 2011 tentang Pedoman Relawan Penanggulangan Bencana.

Brahmantyo, B. (2005). Geologi Cekungan Bandung. Bandung: Institut Teknologi Bandung.

Budi W., N. (2017). The Analysis of Seismicity and Earthquake Energy in Opak-Oya Fault Area Yogyakarta. Jurnal Sains Dasar, 6(2), 109-115.

Hidayat, E., Brahmantyo, B., \& Yulianto, E. (2008). Analisis endapan sagpon pada Sesar Lembang. Jurnal Geoaplika, 3(3), 151-161.

Ibrahim, G., \& Subardjo. (2005). Pengantar Seismologi. Jakarta: 
Badan Meteorologi dan Geofisika.

ISDR, I. S. for D. R. (2004). Living with risk - A global Reinitiatives. Retrieved from

http://www.unisdr.org/files/657_Iw r1.pdf

Lambas. (2009). Modul Ajar Pengintegrasian Pengurangan Risiko Bencana Gempa Bumi. Jakarta: Pusat Kurikulum Badan Penelitian dan Pengembangan Kementrian Pendidikan Nasional.

Maryani, E., \& Furqan, M. H. (2016). Edutourism in Aceh Tsunai Museum (Visitors' Profil and Expectation). In Proceeding Archipelago Tourism: Marine Tourism in Archipelagic Hemisphere.

Rasmid, R. (2014a). Aktivitas Sesar Lembang di Utara Cekungan Bandung. Jurnal Meteorologi Dan Geofisika, 15(2), 129-136. https://doi.org/http://dx.doi.org/10. 31172/jmg.v15i2.182

Rasmid, R. (2014b). Interpretasi Episenter dan Hipposenter Sesar Lembang. Al-Hazen Journal of Physics.

Rohadi, S. (2015). Distribusi Spasial dan Temporal Seismotektonik Wilayah
Subduksi Jawa. Jurnal Meteorologi Dan Geofisika, 16(3), 189-198. https://doi.org/http://dx.doi.org/10. 31172/jmg.v16i3.289

Rysnawati, N. M., Sukarasa, I. K., \& Paramarta, I. B. A. (2009). Analisa Tingkat Bahaya Dan Kerentanan Bencana Gempa Bumi Di Wilayah NTT. Buletin Fisika, 18(1), 32-37.

Shohaya, Nia, J., Chasanah, U., Mutiarani, A., Wahyuni, L., \& Madlazim. (2013). Survey dan Analisis Seismisitas Wilayah Jawa Timur Berdasarkan Data Gempa Bumi Periode 1999-2013 Sebagai Upaya Mitigasi Bencana Gempa Bumi. Jurnal Penelitian Fisika Dan Aplikasinya, 3(2), 18-27. https://doi.org/http://dx.doi.org/10. 26740/jpfa.v3n2.p18-27

Soehatman, R. (2010). Manajemen Bencana. Jakarta: PT. Dian Rakyat.

Van Bemmelen, R. W. (2000). The Geology of Indonesia. (M. Nyhoff, Ed.). Netherland: The Haque.

Villaverde, R. (2009). Fundamental Concepts of Earthquake Engineering. Square Milton Park, UK: Taylor and Francis. 